اثر شيرابه كميوست زباله شهرى بر ويزّى هاى فيزيكى، هيدروليكى، رطوبتى خاك و عملكرد كياه ذرت

\author{
بامداد ترابى فارسانى" و مجيد افيونى'

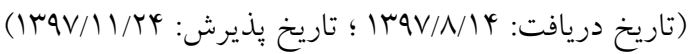

جكيده

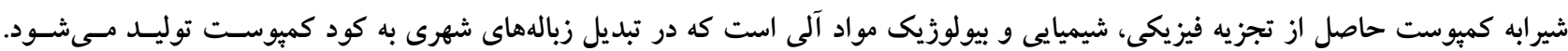

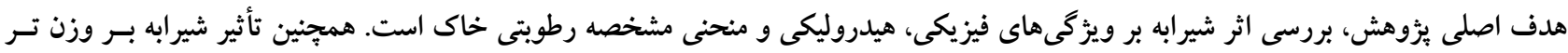

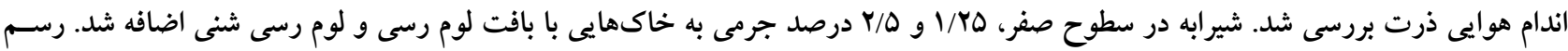

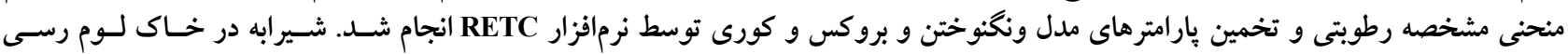

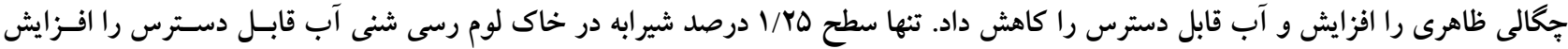

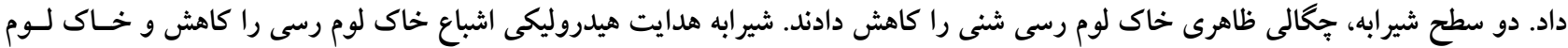

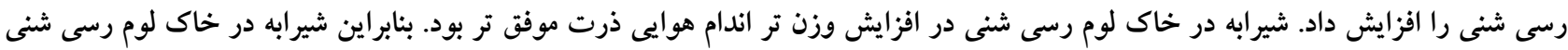

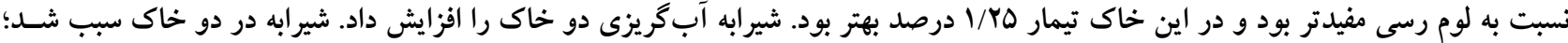
يارامترهاى مدل ونكنوختن و بروكس و كورى نسبت به به شاهد افزايش بيدا كندا.

وازههاى كليدى: شيرابه كميوست، منحنى مشخصه رطوبتى، جحالى ظاهرى، آب قابل دسترس، هدايت هيدروليكى اشباع 
لى و همكاران (Y) گزارش كردند كه بهدليـل كـاهش تخلخـل

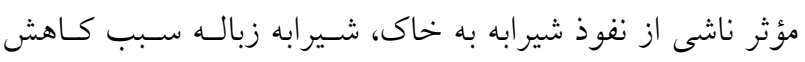

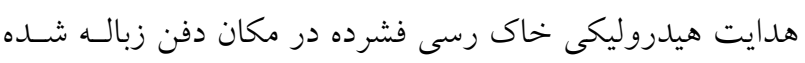

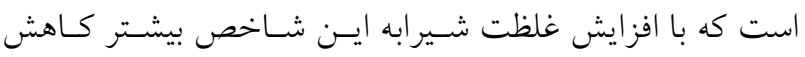

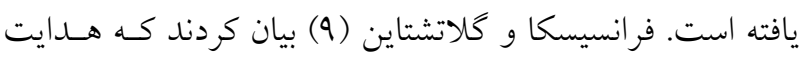

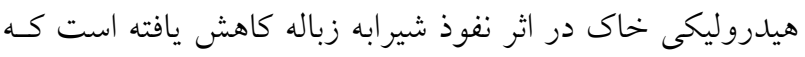

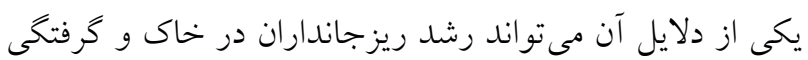

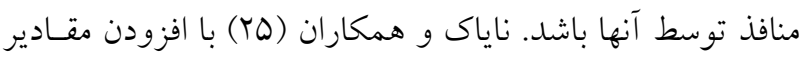

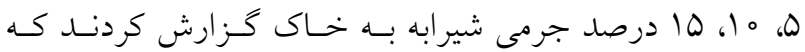
هدايت هيدروليكى و تخلخل خاك در اثر كاربرد شيرابه افزايش يافته است. آنها دليل اين يافته را واكنش شسيميايى بـين شـيرابه اسيدى و كانىهاى رسى بيان كردند.

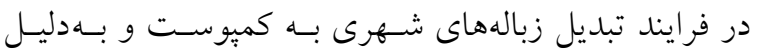
رطوبت زياد زبالههاى خانكى در ايــران، مقــدار زيـادى شـيرابه

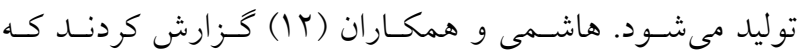
ميانخين دبى خروجى شيرابه كمبوست كارخانهُ كود آلى اصفهان

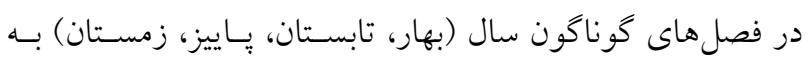

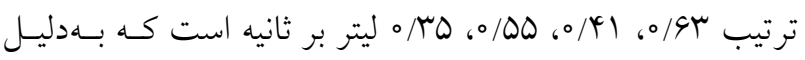

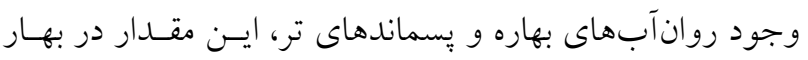

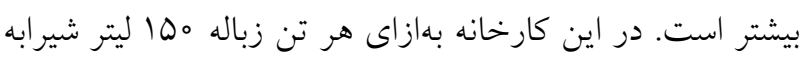

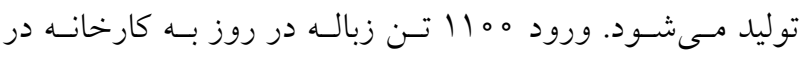

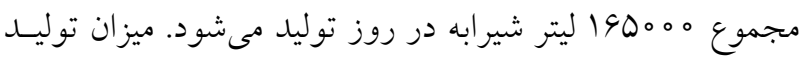

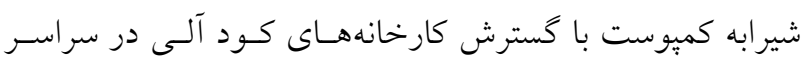
كشور ايران مىتواند به مقدار قابل توجهى برسد.

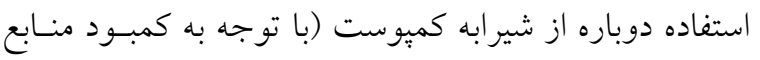

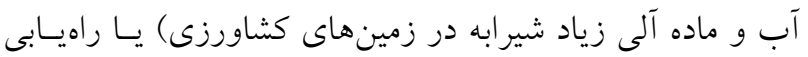

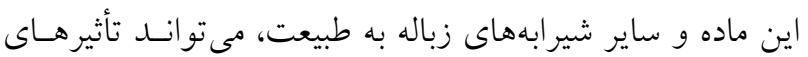

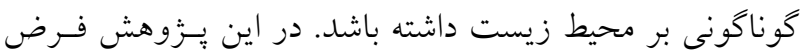

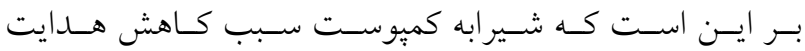

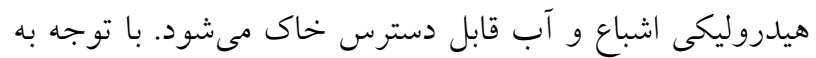

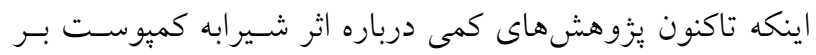

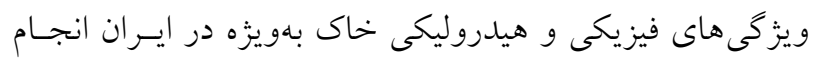

رشد شهرنشينى و ييشرفت صنعت باعث شــده كـه نـرخ توليــ

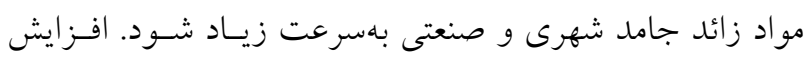

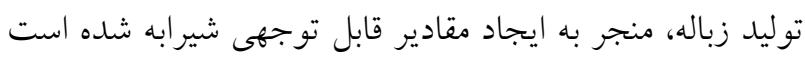

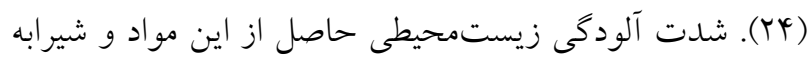

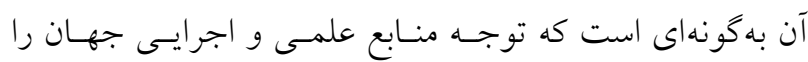

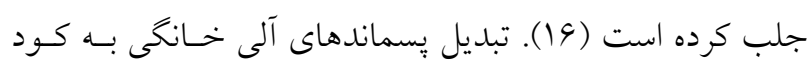

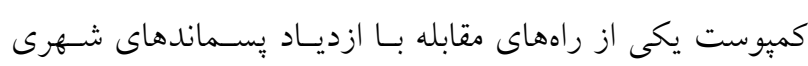

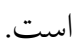

شيرابه كميوست مايع حاصل از تجزيه فيزيكى، شـيميايى و

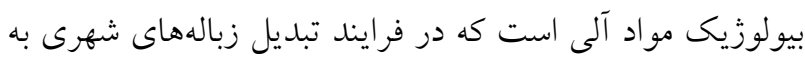
كود كميوست توليد مسى شـود. ميرزايسى و همكــاران (بT) بيـان

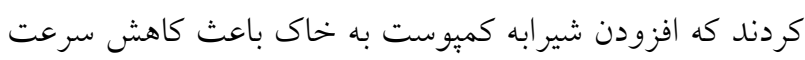
نفوذ در خاك لوم رسى شده است كه مى تواند بـهـهـاطر ميـزان زياد مواد معلق موجود در شير ابه كمبوست باشد.

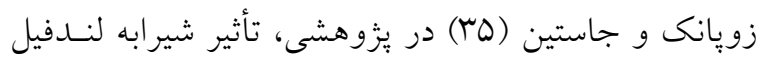

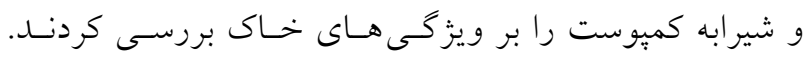

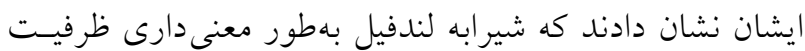

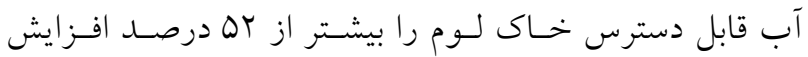

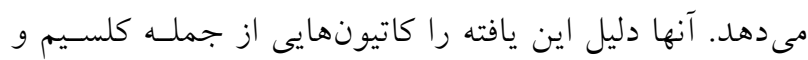

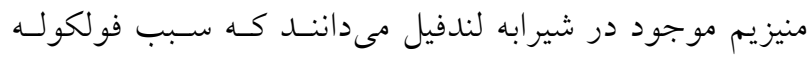

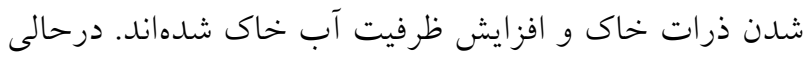

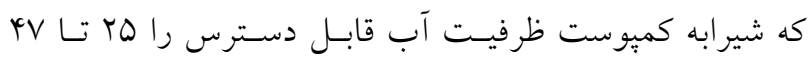

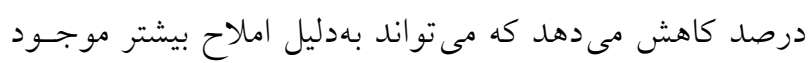

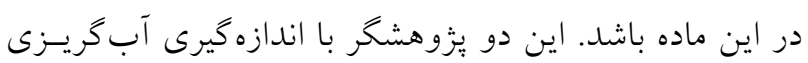

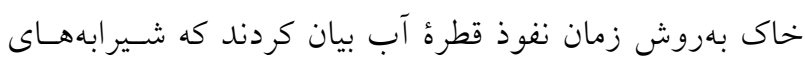

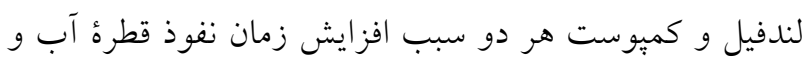

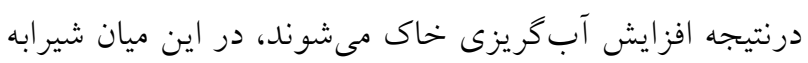

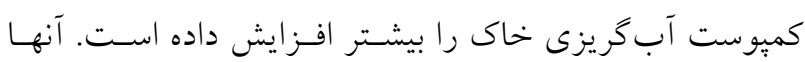

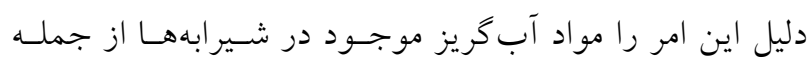

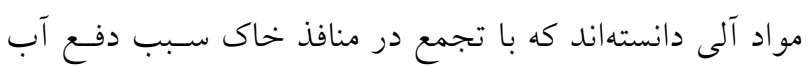

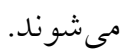


سانتى متر (FC) و عدم خروج تيمارها از كف كلـدان بـهدسـت

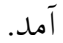

دو هفته يس از اعمال تيمار در هر گلدان داراى ه كيلـوگرم خاك، ه بذر ذرت (رقم ماكسيما) كاشته شد. زمـان دو هفتـهاى بهمنظور پايدار شدن تيمار در خاك و عدم ايجـاد تــش شـورى توسط آن براى بذرهاى ذرت، درنظر گرفته شد. آبيارى در طول مدت كاشت با استفاده از آب شهرى و بهـونهاى انجام شـــ تـا خروجى از كف كلدانها وجود نداشـته باشـد. ه V روز يسس از كاشت (ييش از مرحله زايشـى)، گياهـان ذرت (انــام هـوايى) برداشت شدند و وزن تر آنها اندازهگيرى شد.

\section{آزمايش هاى شيميايى}

عصارهگيرى از شيرابه بهروش هضم تـر (اسـيد نيتريـى .90\% و

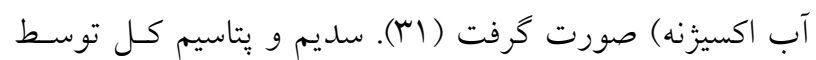
دستخاه فليم فتومتر (Y^)، كلسيم و منيزيم كـل توسـط دسـتخاه جذب اتمى مدل (Perkin-Elmer 3030) در عصارة آماده شـده از شــيرابه كميوسـت و نيتـروزن كـل شـير ابه بـهروش كلــدال اندازه كيرى شد (IV). ماده آلى بهروش اكسيداسيون تر در تيمار

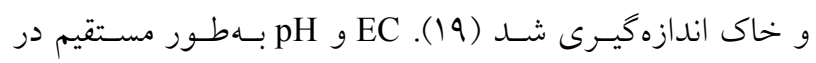
شيرابه كميوست و براى خاك در عصاره گل اشباع اندازه خيـرى شد. مقدار سديم محلول خاك با دستخاه فلـيم فتـومتر (YN) و مجموع كلسيم و منيزيم محلول بهروش تيتراسيون با استفاده از معرف اريو كروم بلكتسى (EBT) و تيتـر كنــده (EDTA) در

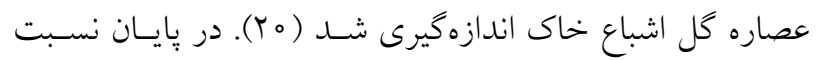
جذب سديم محلول (SAR) در خاى اندازهگيرى شد (r). براى اندازهيرى ماده خشك شيرابه ها كرم از آن را وزن كرده و بـه

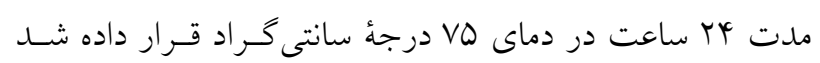

\section{آزمايشهاى فيزيكى و هيدروليكى خاك}

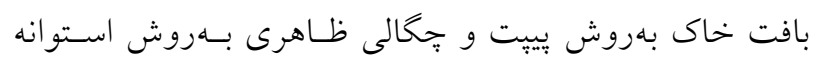

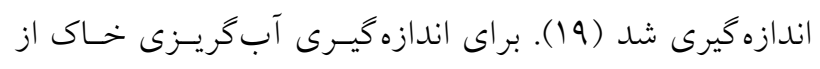

شده است؛ هدف اصلى اين يزوهش بررسى اتــر ايسن مـايع بـر

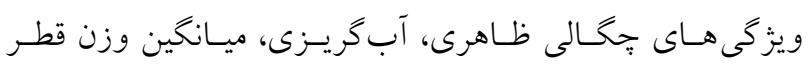
خاكدانههـا، نقـاط رطـوبتى مهـم، آب قابـل دسـترس، هــدايت هيدروليكى اشباع و بهويزه منحنى مشخصه رطوبتى است.

\section{مواد و روشها}

اين يززوهش در كلخانه يزوهشى دانشـكده كشـاورزى دانشـاه

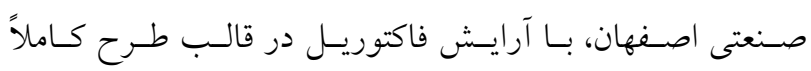
تصادفى با ثا تكرار انجام شد. شيرابه كميوست زباله شهرى (بــ

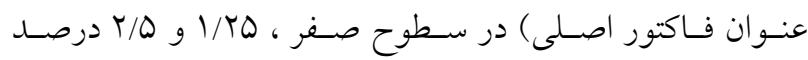

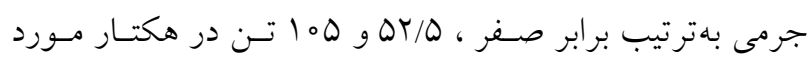

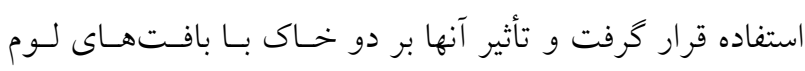
رسى و لوم رسى شنى (بهعنـوان فـاكتور فرعى) و رشــ گيـاه ذرت، مورد بررسى قرار كرفت. رسم منحنى مشخصه رطوبتى و

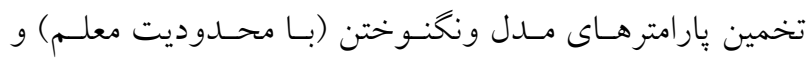
بروكس و كورى براى دو خاك مورد آزمايش توسـط نـرمافـزار انجام شد. تجزيهوتحليل آمارى با استفاده از نـرمافـزار و و آزمـون مقايسـه ميـانخين بـهـروش SAS 9.4 آمارى ه درصد انجام شد.

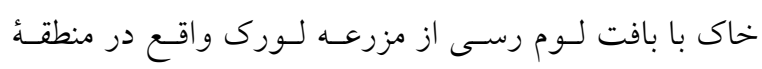

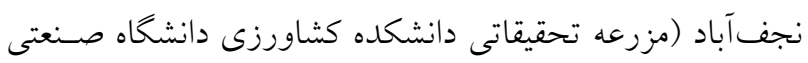

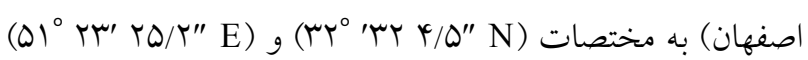

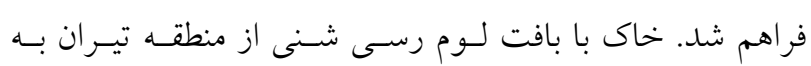

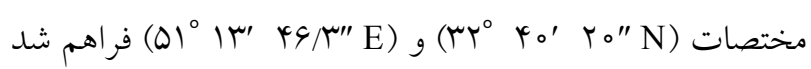
(عمق نمونهبردارى خاكها صفر تا مبانتى ستـر بـود). شـيرابه

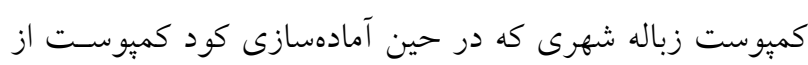
زباله شهرى ايجاد شده است از كارخانهُ كود آلى اصـفهان تهيـهـ شد. شيرابه كميوست شورى زيـادى دارد بـههمـين دليـل بـراى كاهش اثر شورى و همخن شدن بهتر با خـاك بـه هـر كــام از تيمارهاى شيرابه، سه برابر آب مقطر اضافه شد. مقدار سه برابـر با توجه به حداكثر سطح تيمار، رطوبـت خـاك در مكـش هسر 


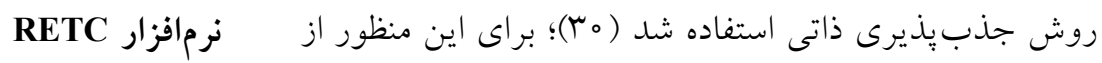

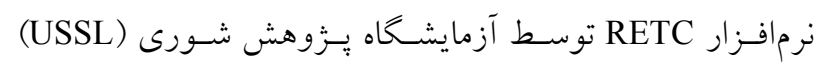

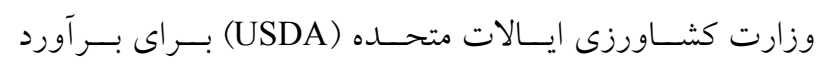

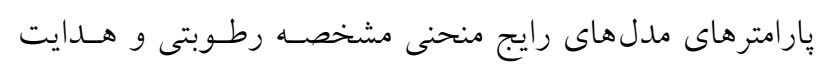

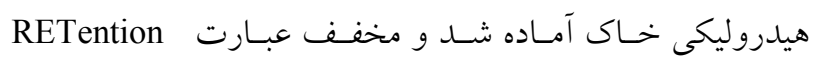

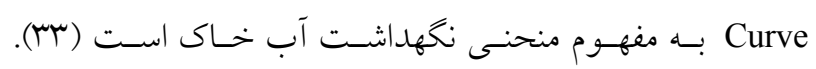

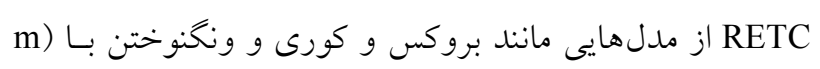

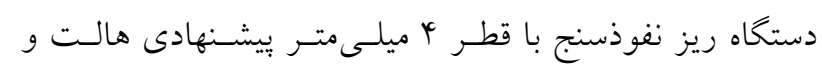

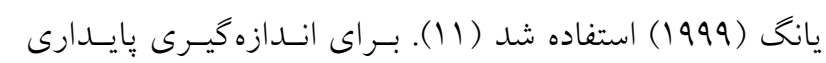

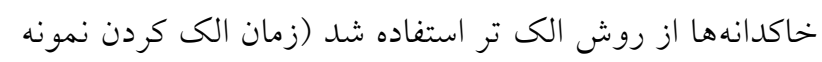

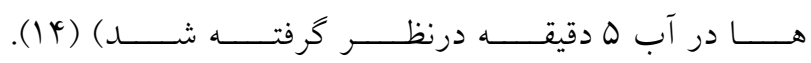

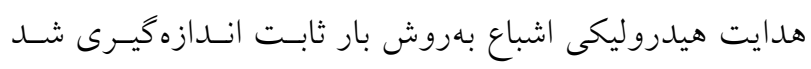

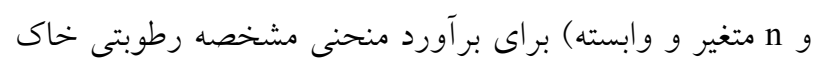

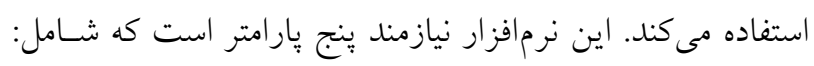

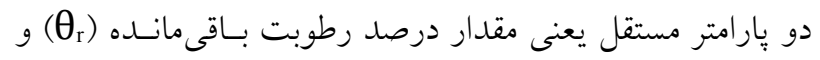

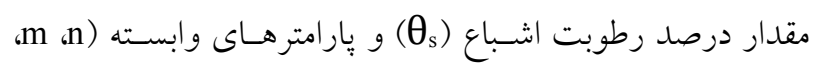

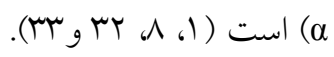

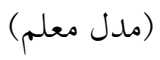

$m=1-1 / n$

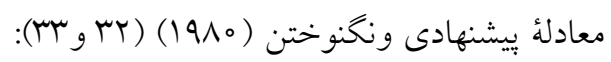

$\theta \theta=\theta_{\mathrm{r}}+\left(\theta_{\mathrm{s}}-\theta_{\mathrm{r}}\right)\left[1+(\alpha \mathrm{h})^{\mathrm{n}}\right]^{-\mathrm{m}}$

رطوبـت خـاك در مكـش معـادل ، ر ، ربـت

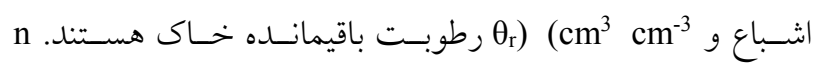

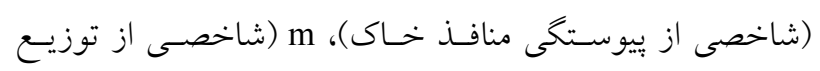

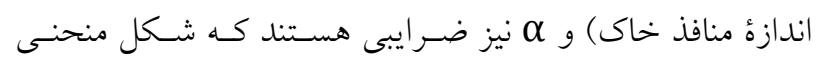

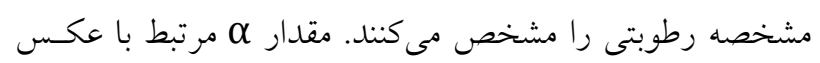
مكش ماتريك در نقطه عطف منحنى است.

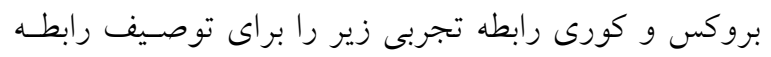

بين مقدار رطوبت و مكش ماتريك ارائه دادهاند (^):

$\theta=\theta_{\mathrm{r}}+\left(\theta_{\mathrm{s}}-\theta_{\mathrm{r}}\right)(\alpha \mathrm{h})^{-\lambda}$

$\left\{\begin{array}{lc}\theta=\theta_{\mathrm{r}}+\left(\theta_{\mathrm{s}}-\theta_{\mathrm{r}}\right) & (\alpha \mathrm{h})^{-\lambda} \quad \alpha \mathrm{h}>1 \\ \theta=\theta_{\mathrm{s}} & \alpha \mathrm{h} \leq 1\end{array}\right.$

ג ضريبى است كه از طريق بـرازش دادههـاى h و $\theta$ بـهدسـت

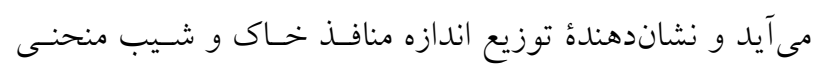

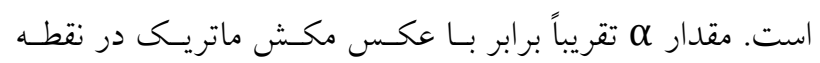

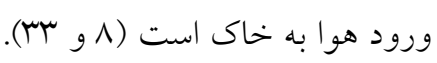

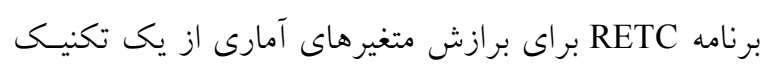

منحنى مشخصهُ رطوبتى خاى

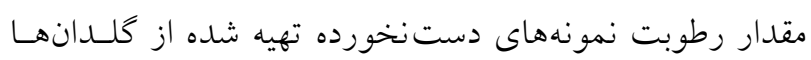

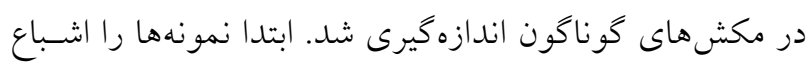

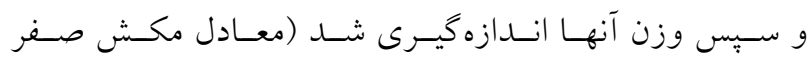

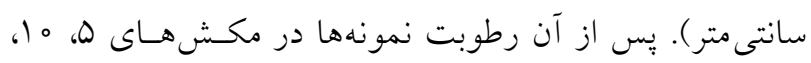

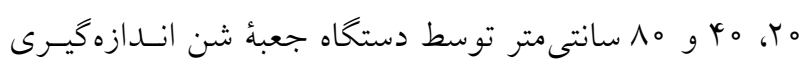

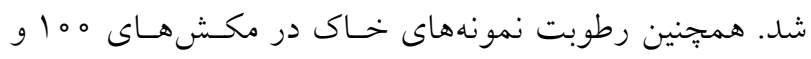

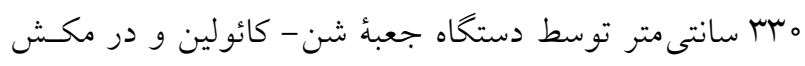

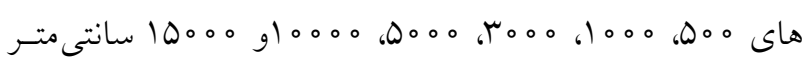

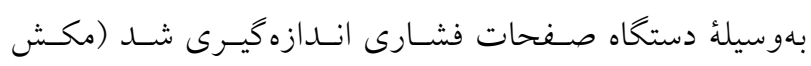

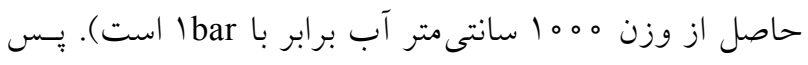

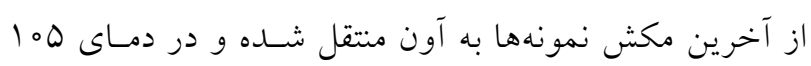

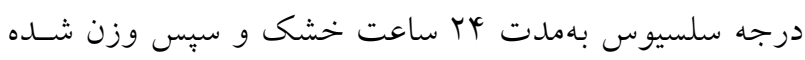

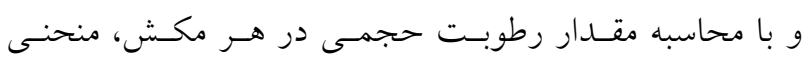

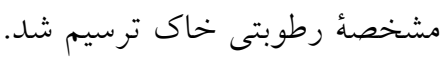

\section{برخى از ويزگى هاى رطوبتى خاى}

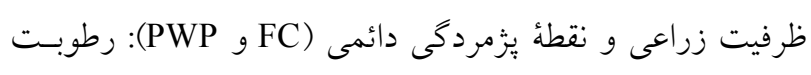

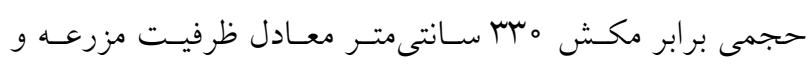

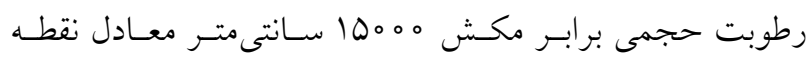

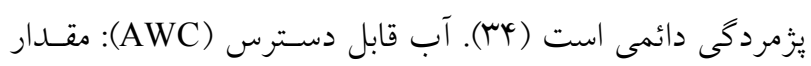

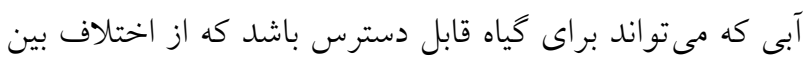

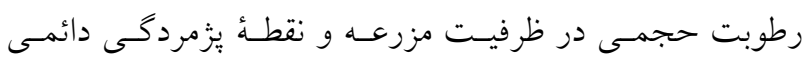

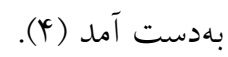


جدول ا. ويزّكى هاى شير ابه كميوست مورد استفاده

\begin{tabular}{|c|c|c|c|c|c|c|c|c|c|c|}
\hline $\mathrm{C} / \mathrm{N}$ & SAR & $\mathrm{K}$ & $\mathrm{Na}$ & $\mathrm{Mg}$ & $\mathrm{Ca}$ & نيتروزن كل & كربن آلى & ماده خشك & $\mathrm{EC}$ & $\mathrm{pH}$ \\
\hline & & \multicolumn{4}{|c|}{$\mathrm{g} / \mathrm{L}$} & \multicolumn{2}{|c|}{ درصد در ماده خشك } & $(\%)$ & $(\mathrm{dS} / \mathrm{m})$ & \\
\hline$\varphi / 0$ & $11 / r$ & $r / l$ & rq & $0 / 9$ & $r / \Lambda$ & $\varphi / \Delta$ & $r \circ / r$ & $\Delta / \mu$ & $T Y / \mu$ & $Y / Y$ \\
\hline
\end{tabular}

SAR نسبت جذب سديم محلول، بهغير از نيتروزن كل ميزان بقيه عناصر در يك ليتر شيرابه گزارش شده است. C/N: نسـبت كربن بـه نيتـروزن

با ويزَگى هاى دو گانه (مثبت و منفى) است.

اثر شيرابه كميوست بر pH خاك

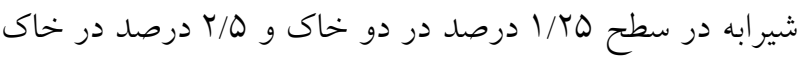

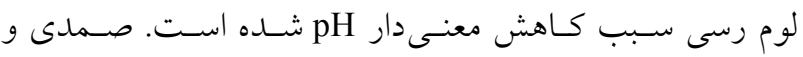
رضايور (Yq) نيز كاهش pH خاك را بر اثر استفاده از شـيرابه كزارش كردهاند. يكى از دلايل كاهش pH خاك مى تواند بهدليل pH اسيدى شيرابه باشد. همجنين تجزيه زيستى ماده آلى شيرابه در خاك نيز منجر به تشكيل اسيدهاى آلى و كـاهش pH خـاك مىشود (YY). سطح T/D درصد شير ابه در خاك لوم رسى شسنى

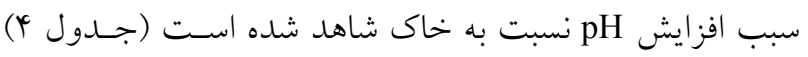

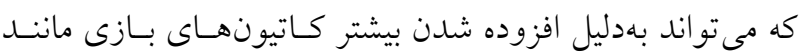

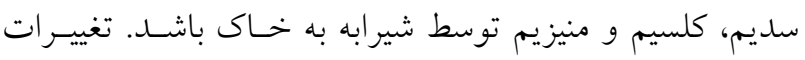
pH

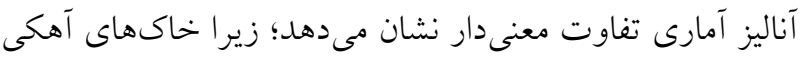

$$
\text { ايران ويزگى بافرى زيادى دارند. }
$$

اثر شيرابه كمبوست بر شورى و SAR خاك شيرابه در دو سطح، سبب افزايش معنى دار شورى خاك لوم رسى سرى

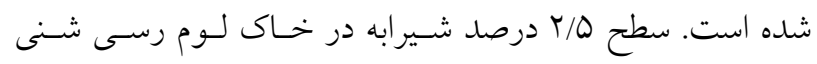
موجب افزايش معنى دار شورى خاك نسبت به شاهد شـده اسـت (جدول (₹). اين يافته مىتواند بهدليل شورى زياد شير ابه باشد. شيرابه در دو خاك سبب افزايش معنى دار نسبت جـذب ســـيم محلول خاك (SAR) شده است. سـطح ب/ Y درصـد شسير ابه در دو
ركرسـيونى جنسـدمتغيره و غير خطسى اسـتفاده مسى كنسد كــ

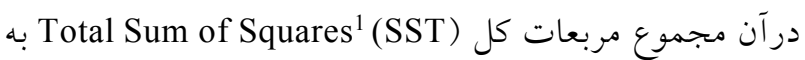

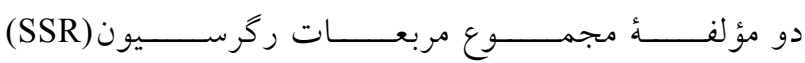
Regression Sum of Squares ${ }^{2}$ (خطا) (Residual Sum of Squares ${ }^{3}$ (SSQ) تقسيم مى شئود.

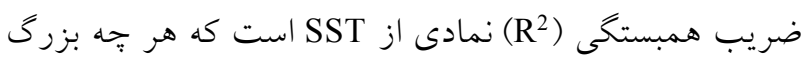
تر باشد دقت مدل ركرسيونى بيشتر خوا اهد شد. مطمئنترين

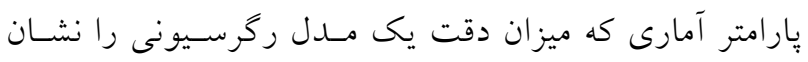

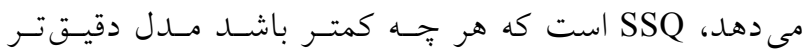

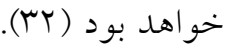

$\mathrm{SSQ}=\sqrt{\frac{\sum_{\mathrm{i}=1}^{\mathrm{j}}\left(\mathrm{C}_{\mathrm{ic}}-\mathrm{C}_{\mathrm{im}}\right)^{2}}{\mathrm{~J}-1}}$

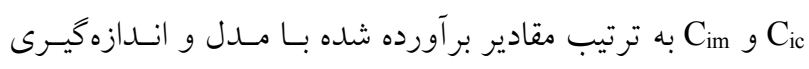

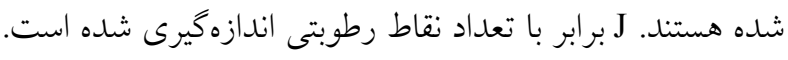

\section{نتايج و بحث شيرابه كميوست}

شيرابه داراى مقدار قابل توجهى كربن آلى و نيتروزن كل در مـاده

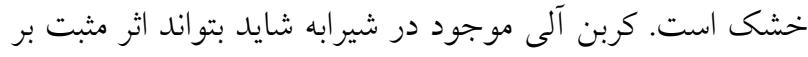

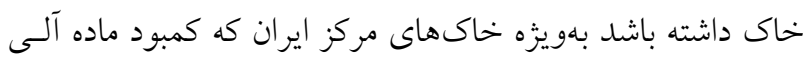
دارند. شيرابه داراى pH اسيدى، شورى و SAR بالا است (جدول 1). شورى و SAR بالا را مى توان دو ويزگى منفى شسيرابه درنظـر كرفت. pH اسيدى بهدليل وجود موادى از جملـه اسـيد لاكتيك، اسيد استيك، اسيد آمينه مى تواند باشد (ه). بنابراين شيرابه مادهاى تهاى 
جدول r. ويز كىهاى خاكهاى مورد بررسى

\begin{tabular}{|c|c|c|c|c|c|c|c|c|c|c|}
\hline بافت خاك & سيلت & رس & شن & $\begin{array}{c}\text { קجالى ظاهرى } \\
\left(\mathrm{g} / \mathrm{cm}^{3}\right)\end{array}$ & SAR & $\begin{array}{c}\text { نيتروزن كل } \\
\text { (\%) }\end{array}$ & $\begin{array}{c}\text { ماده آلى } \\
\text { (\%) }\end{array}$ & $\begin{array}{c}\mathrm{EC} \\
(\mathrm{dS} / \mathrm{m})\end{array}$ & $\mathrm{pH}$ & \\
\hline لوم رسى & $\varphi \Delta / V$ & $M T / 4$ & $r 1 / 9$ & $1 / 49$ & $9 / 0$ & $0 / 1$ & $1 / 9$ & $1 / \pi$ & $\Lambda / \Delta$ & مزرعه لورى \\
\hline لوم رسى شنى & $|V /|$ & $\mu_{\circ / \Lambda}$ & $\Delta r / 1$ & $1 / 44$ & $r / 0$ & or & $\circ / 4$ & $0 / 9$ & $V / 9$ & تيران \\
\hline
\end{tabular}

جدول r. تجزيه واريانس اثر شيرابه كميوست بر برخى ويزّى هاى شيميايى خاك مورد بررسى و عملكرد گياه ذرت

\begin{tabular}{|c|c|c|c|c|c|c|}
\hline \multicolumn{5}{|c|}{ ميانخين مربعات } & \multirow[b]{2}{*}{ آزادى } & \multirow[b]{2}{*}{ منبع } \\
\hline 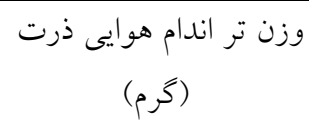 & ماده آلى & SAR & $\begin{array}{l}\text { شورى } \\
(\mathrm{dS} / \mathrm{m})\end{array}$ & $\mathrm{pH}$ & & \\
\hline
\end{tabular}

\begin{tabular}{|c|c|c|c|c|c|c|}
\hline$r \circ 9 / \wedge V^{* *}$ & $\circ / Y I^{* *}$ & $\Gamma_{\circ / Q 1 * *}$ & $\circ / N G * *$ & $\circ / \Delta \Delta_{* *}$ & r & شير ابه \\
\hline$\| \kappa \circ 4 / 40 * *$ & $9 / .9 * *$ & YGN/YV** & $\varphi / \Lambda \mu^{*} * *$ & $Y / \circ \wedge * *$ & 1 & خاى \\
\hline $9 \Lambda / 94 *$ & o/० Y* & $\circ / \Lambda I^{* *}$ & $\circ / 1 Q^{* *}$ & $\circ / Y I^{* *}$ & r & شير ابه × خاك \\
\hline$T Y / Y_{0}$ & $0 / 004$ & $\% / \wedge$ & \%or & $\% \circ \mathrm{V}$ & 11 & خطا \\
\hline
\end{tabular}

جدول f. مقايسه ميانكين اثر متقابل شيرابه كمبوست با خاك بر برخى از ويزّىهاى شيميايى و ذرت

\begin{tabular}{|c|c|c|c|c|c|c|}
\hline$r / Q \%$ & لوم رسى شن & شاهد & $r / Q \%$ & لوم رسى & شاهد & ويزگى \\
\hline $\mathrm{V} / \wedge^{c}$ & $V / \varphi^{e}$ & $V / 9 d$ & $\Lambda / \mu \circ b$ & $\mathrm{~V} / \mathrm{Vc}^{\mathrm{c}}$ & $\Lambda / \Delta^{a}$ & $\mathrm{pH}$ \\
\hline$\circ / 9 d$ & $\circ / \mathrm{Ved}^{2}$ & $\circ / 9 \mathrm{e}$ & $r / l^{a}$ & $1 / 9 \mathrm{~b}$ & $1 / \mu_{c}$ & شورى (dS/m) \\
\hline $9 / 4 d$ & $r / v e$ & $r^{f}$ & $\mid r / V^{a}$ & $10 / 1^{b}$ & $Q / Q^{c}$ & SAR \\
\hline $0 / 9 d$ & $\circ / 9 \mathrm{~d}$ & $\circ / e^{2}$ & ra & $1 / \wedge^{b}$ & $1 / 9 \mathrm{c}$ & ماده آلى (.) \\
\hline$r \Delta / \mu^{c}$ & $r V / q c$ & $r Q^{d}$ & $V / / 9 b$ & $\Lambda Y / M^{\mathrm{a}}$ & $V Q / / a b$ & وزن تر اندام هوايى ذرت (كرم) \\
\hline
\end{tabular}

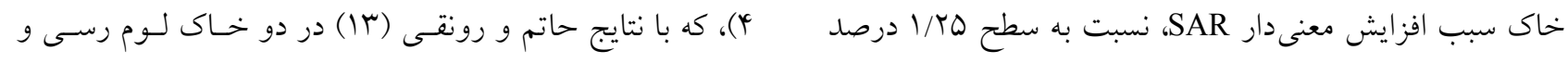

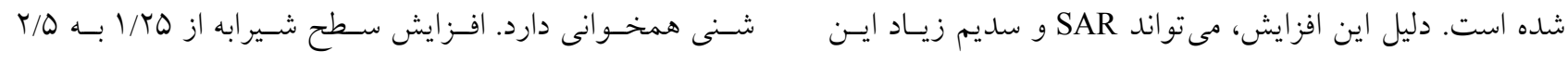

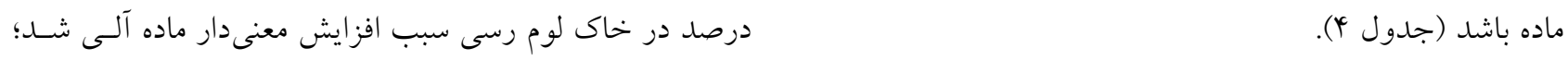

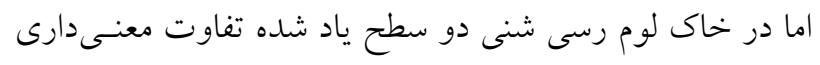

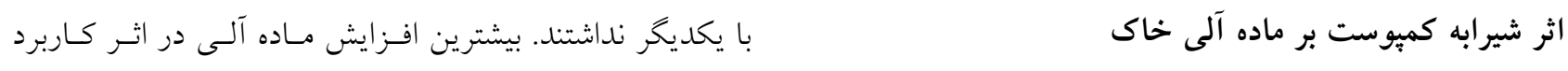

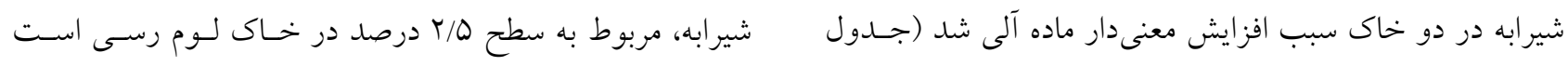


خاك لوم رسى شنى سبب كاهش معنى دار خجالى ظـاهرى شـده

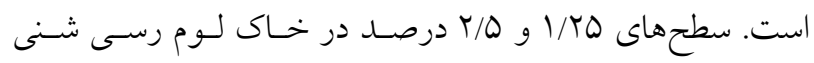

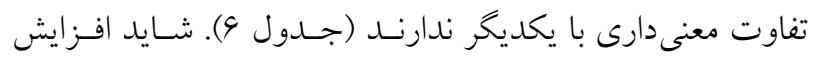

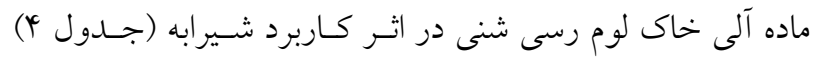

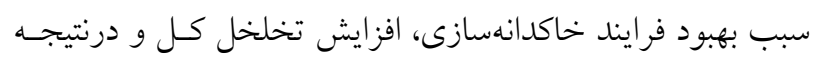
كاهش معنى دار جّالى ظاهرى شده است.

\section{اثر شيرابه كميوست بر شاخص آبگريزى خاك}

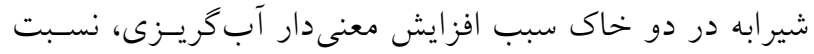

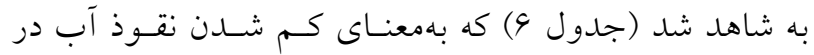
خاك (در زمانهاى ابتدايى نقوذ) اسـت. ايسن يافتـه بـا نتسايج

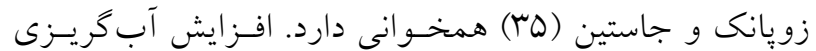

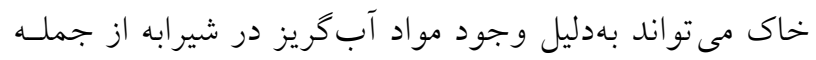

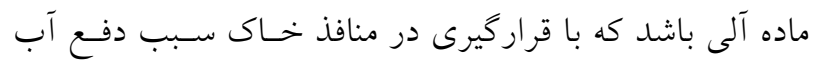

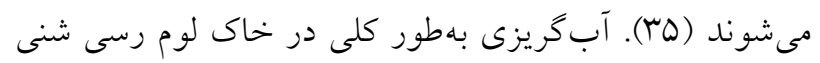

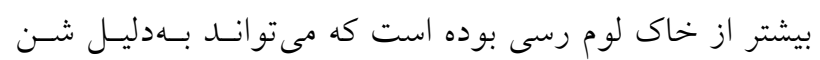

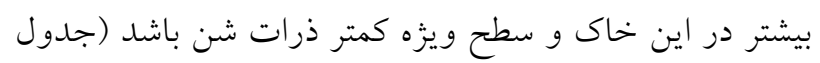

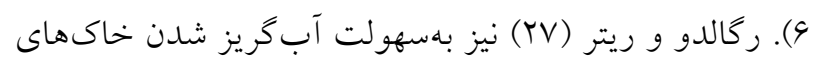

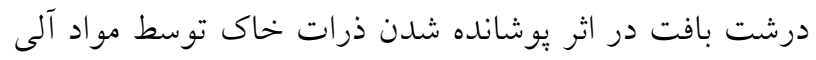

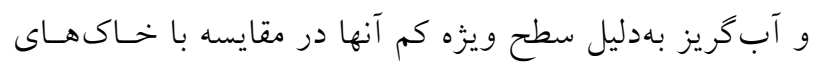

$$
\text { ريزبافت اشاره كردهاند. }
$$

\section{اثر شيرابه كمبوست بـر ميـانخين وزنسى قطـر خاكدانسهــا}

(MWD)

دو سطح شيرابه در خـاك لـوم رسسى سـبب افـزايش معنسى دار ميانخين وزنى قطر خاكدانهها شدهاند (جدول 9). ايـن افـزايش

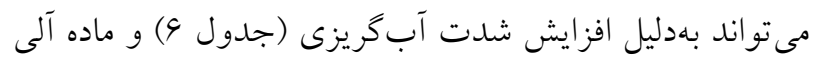

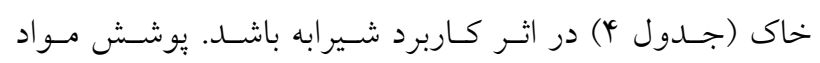

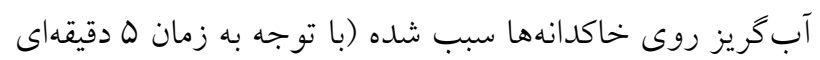

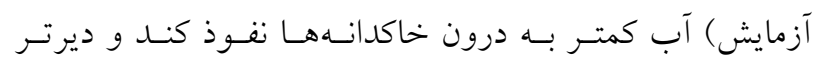
متلاشى شوند. افزايش EC خاك توسط تيمار شسيرابه در خـاك

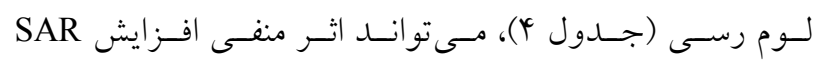

(جدول Y). افزايش ماده آلى مى تواند بهدليـل كـربن آلى قابـل توجه شيرابه باشد (جدول ()). اثر شيرابه كمبوست بر وزن تر اندام هوايى گياه ذرت

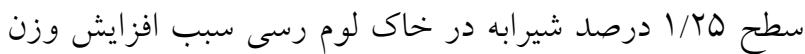
تر شده است اما اين افزايش نسـبت بـه شـاهد معنسى دار نبـوده است. سطح r/D درصد شيرابه سبب كـاهش معنسى دار وزن تـر

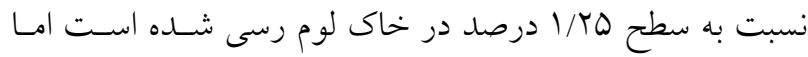
اين كاهش نسبت بـه شـاهد معنسى دار نبـوده اسـت. ايسن يافتـه مى تواند بهسبب افزايش شـورى و SAR خـاك در اثـر كـاربرد

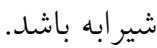
دو سطح شيرابه در خـاك لـوم رسى شـنى سـبب افـزايش معنى دار وزن تر نسبت به شاهد شده است. اين يافتسه بـا نتـايج

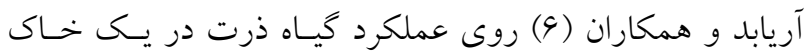

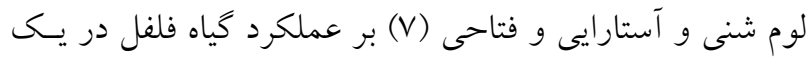

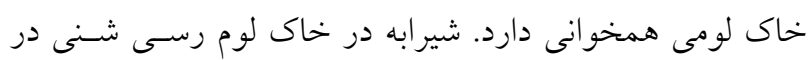

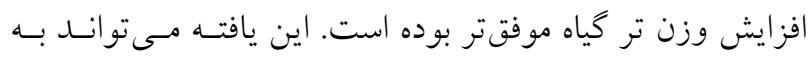

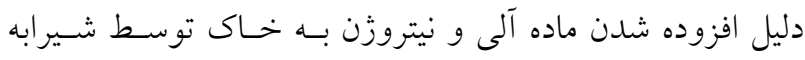

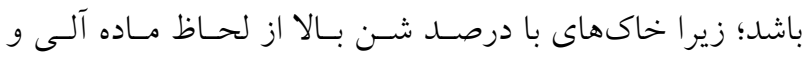

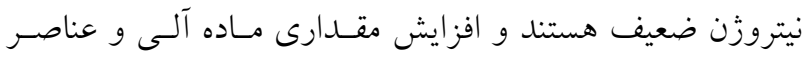
غذايى مىتواند افزايش عملكرد را در يى داشته باشد.

اثر شيرابه كميوست بر جُالى ظاهرى خاى دو سطح شسيرابه در خـاك لـوم رسىى، سـبب افـزايش معنسى دار

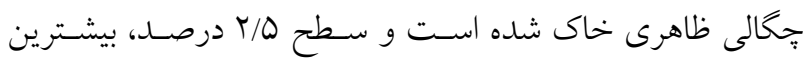

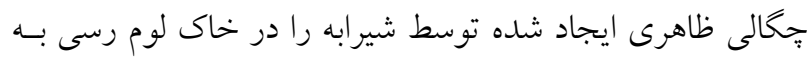

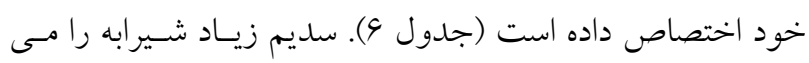
توان به اين موضوع مرتبط دانست؛ يس از ورود شيرابه به خـاك،

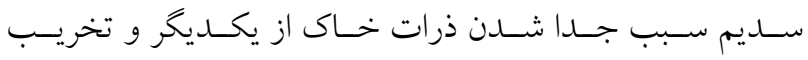
ساختمان خاك شده است. ذرات ير اكنده شده حاصل از تخريسب

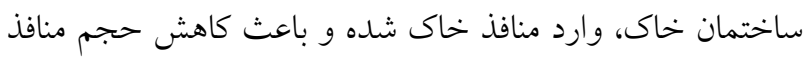

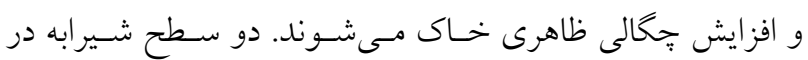


جدول ه. تجزيه واريانس اثر شيرابه كمبوست بر برخى ويزگگهاى فيزكى خاكهاى مورد بررسى

\begin{tabular}{|c|c|c|c|c|c|c|c|c|}
\hline \multicolumn{7}{|c|}{ ميانگين مربعات } & \multirow{2}{*}{ درجه } & \multirow{2}{*}{ تغيير ات } \\
\hline $\begin{array}{c}\mathrm{KS} \\
(\mathrm{cm} / \mathrm{h})\end{array}$ & $\begin{array}{c}\mathrm{AWC} \\
\left(\mathrm{cm}^{3} / \mathrm{cm}^{3}\right) \%\end{array}$ & $\begin{array}{c}\mathrm{PWP} \\
\left(\mathrm{cm}^{3} / \mathrm{cm}^{3}\right) \%\end{array}$ & $\begin{array}{c}\mathrm{FC} \\
\left(\mathrm{cm}^{3} / \mathrm{cm}^{3}\right) \%\end{array}$ & $\begin{array}{l}\text { MWD } \\
(\mathrm{mm})\end{array}$ & RI & $\begin{array}{c}\mathrm{BD} \\
\left(\mathrm{g} / \mathrm{cm}^{3}\right)\end{array}$ & & \\
\hline $10 / 1 \mathrm{~V} * *$ & $1 / 90 * *$ & $r \mu / 4 q * *$ & IY/Aץ** & ॰/॰ץ** & $\circ / 49 * *$ & ०/००ץ** & r & شير ابه \\
\hline $90 / 11 \% * *$ & . & $\aleph_{\wedge} ৭ / 4 \hookrightarrow * *$ & 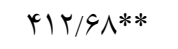 & $\circ / \circ \circ \vee * *$ & $\circ / \wedge * *$ & $0 / 01 * *$ & 1 & خاى \\
\hline $19 / 94 * *$ & $\Gamma / 99 * *$ & $\mu_{\circ} / / V^{*} *$ & YY/RY** & $\circ / \circ{ }^{\prime} * *$ & $\circ / 04 * *$ & $\circ / \circ r_{* *}$ & r & شيرابه × خاى \\
\hline $0 / 1$ & $\circ / 00$ &.$/ 94$ &.$/ 94$ & $0 / 0004$ & $0 / 0009$ & ०/०००Y & 11 & خطا \\
\hline
\end{tabular}

* نشاندهنده معنى دار بودن در سطح آمارى ه درصد،** نشاندهندة معنى دار بودن در سطح آمارى ا درصد است. جخالى ظاهرى (BD)، شاخص

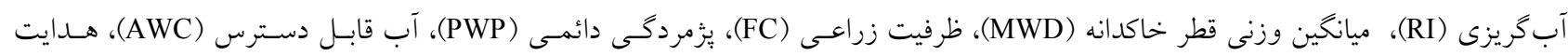

هيدروليكى اشباع (KS)

جدول و. مقايسه ميانگين اثر متقابل شيرابه كمبوست با خاك بر برخى از ويزگى هاى فيزيكى

\begin{tabular}{|c|c|c|c|c|c|c|c|}
\hline \multicolumn{3}{|c|}{ لوم رسى شنى } & \multicolumn{3}{|c|}{ لوم رسى } & \multirow{2}{*}{ واحد } & \multirow{2}{*}{ ويز كى } \\
\hline $\mathrm{r} / \mathrm{Q} \%$ & $1 / T \Delta \%$ & شاهد & $r / \Delta \%$ & $1 / T \Delta \%$ & شاهد & & \\
\hline$l / V^{c}$ & $1 / \pi q^{c}$ & $1 / 4 y b$ & $1 / \Delta Y^{a}$ & $1 / 4 y b$ & $1 / \mu^{4 c}$ & $\left(\mathrm{~g} / \mathrm{cm}^{3}\right)$ & جّخالى ظاهرى \\
\hline$r / q^{a}$ & $r / q^{a}$ & $r / I^{d}$ & $r / Y^{c}$ & $r / \Delta^{\mathrm{b}}$ & re & - & RI \\
\hline$\circ / T y b$ & $\circ / T V^{b}$ & $\circ / T y b$ & $\circ / \Gamma \Delta^{a}$ & $0 / Y^{c}$ & $\circ / \circ q^{d}$ & $\mathrm{~mm}$ & MWD \\
\hline$r Q / r^{e}$ & $Y Y / T^{e}$ & $r \& / \mathrm{N}^{\mathrm{d}}$ & $r \varphi / q^{a}$ & 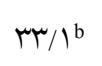 & $\mu \mid / \mu^{c}$ & $\left(\mathrm{~cm}^{3} / \mathrm{cm}^{3}\right) \%$ & $\mathrm{FC}$ \\
\hline $\mathrm{IV} / \mathrm{Q}^{\mathrm{d}}$ & $14 / 9^{\mathrm{e}}$ & $1 \Lambda / Y^{d}$ & $r \wedge^{\mathrm{a}}$ & $Y Y / V^{b}$ & $r I / \wedge^{c}$ & $\left(\mathrm{~cm}^{3} / \mathrm{cm}^{3}\right) \%$ & PWP \\
\hline$V / V^{c}$ & $q / 4^{\mathrm{a}}$ & $\Lambda / 4 b$ & $\Lambda / \Delta^{\mathrm{b}}$ & $\Lambda / \Gamma^{\mathrm{b}}$ & $q /{ }^{<a}$ & $\left(\mathrm{~cm}^{3} / \mathrm{cm}^{3}\right) \%$ & AWC \\
\hline$\Delta / /^{b}$ & $9 / 9^{a}$ & $1 / 9^{c}$ & $0 / \mathrm{re}^{\mathrm{e}}$ & $\circ / \mu^{e}$ & $\circ / 9^{d}$ & $\mathrm{~cm} / \mathrm{h}$ & $\mathrm{Ks}$ \\
\hline
\end{tabular}

خاك توسط اين تيمار (جدول \&) را بر يايدارى ساختمان خـاك اثر شيرابه كميوست بر ظرفيت زراعى، نقطه بزّمردگى دائمى

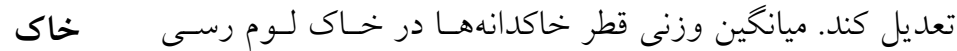
شيرابه در خاك لوم رسسى سـبب افـزايش معنسى دار دو نقطـه شنى در اثر كاربرد شيرابه نسبت بـه خـاك شـاهد زيـادتر شـده رطوبتى (ظرفيت زراعى و وزّمردخى دائمسى) شــده اسـت؛ بــا است؛ اما ايـن افـزايش معنسى دار نبـوده اسـت. بيشـترين ميـزان

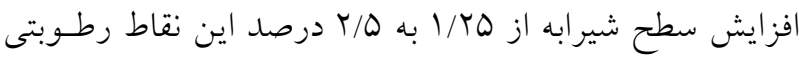
ميانخين وزنى قطر خاكدانهها در خاكهاى تيمار شده با شـيرابه افزايش معنى دارى بيدا كردهاند (جدول 9). دليل اين يديده را در بافت لوم رسى و سـطح T/D درصــ شـيرابه بـهدسـت آمـــ مىتوان به افزايش ماده آلى نسبت داد از سوى ديخـــ افـزايش

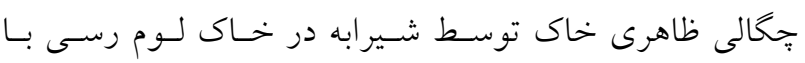
كاهش حجم منافذ، مى تواند خروج آب از نمونههاى خـاى را

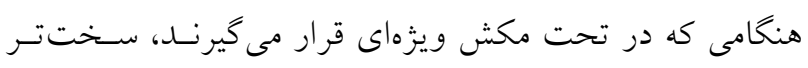
(جدول 9) كه مىتواند بهدليل ماده آلى بيشتر در اين خاك باشد (جدول †)؛ در واقع مىتوان گفت كه تأثير ماده آلى بر پيايسدارى ساختمان خاى در زمانهاى كوتاه الك كردن بيشتر قابـل توجـه.

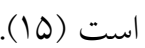


تخلخل كل خاك لوم رسى دراثر كاربرد اين تيمار باشــ؛ بـا

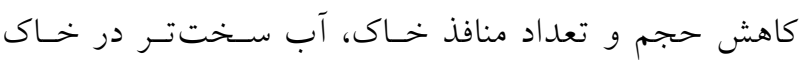
جريان يبدا كرده است. همجنين حضور مواد معلق در شيرابه

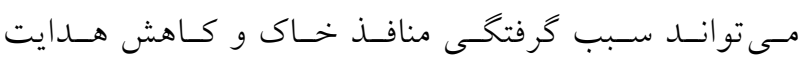

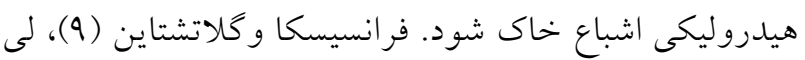

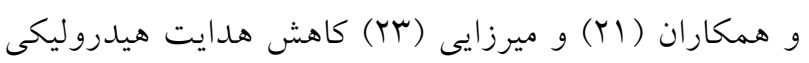
اشباع را در اثر كاربرد شيرابه گزارش كردهاند. دو سطح شيرابه در خاك لوم رسى شـنى سـبب افـزايش معنى دار هدايت هيدروليكى اشباع خاك شده است (جـدول

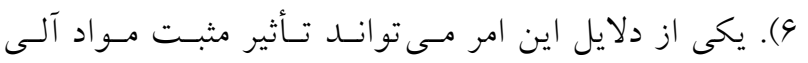

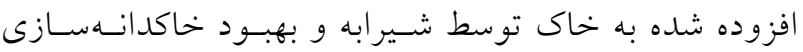

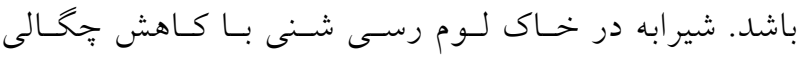
ظاهرى (جدول 9) تعداد منافذى را كه مىتواند آب را عبور دهند افزايش داده است و بنابراين اين شاخص افزايش يبيـدا

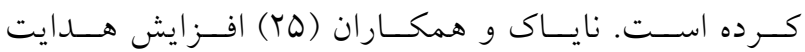

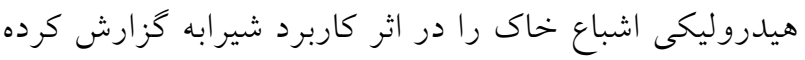

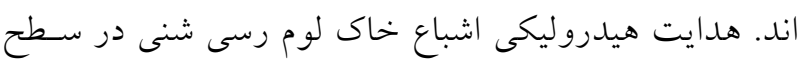

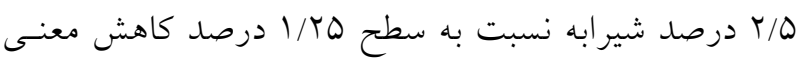

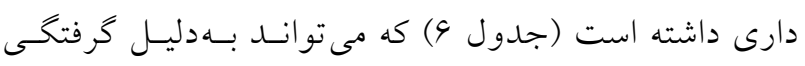
بيشتر منافذ خاك توسط مـواد معلـق در اثــ كـاربرد بيشـتر شير ابه باشد.

اثر شيرابه كمبوست بر پارامترهاى هيدروليكى

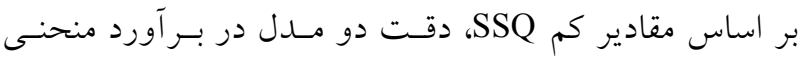

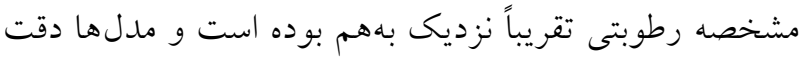

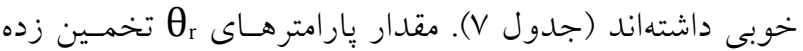
شده توسط دو مدل ونخحنوختن و بـروكس و كـورى در خـاى

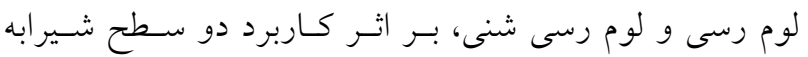
نسبت به خاك شاهد افزايش يافته است (بهجز شده توسط مدل ونخنوختن در خاك لوم رسى شنى تيمار شده

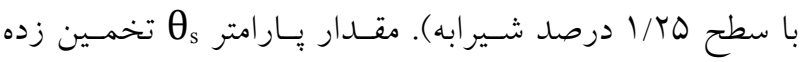
شده توسط دو مدل ياد شده در خاك لـوم رسسى شـنى تيمـار
كند. شير ابه در خاك لوم رسى شـنى سـبب كـاهش معنسىدار

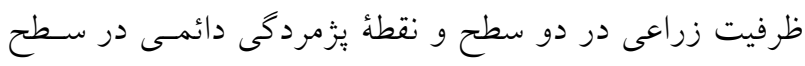

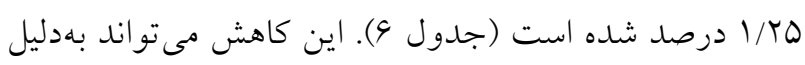

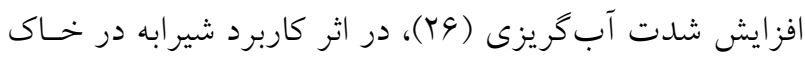
لوم رسى شنى باشد. تفاوت معنسى دارى بـين ظرفيـت زراعسى

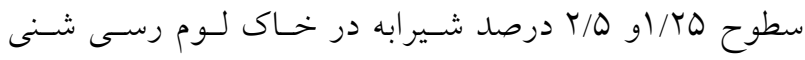

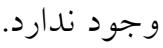
اثر شيرابه كميوست بر آب قابل دسترس خاك

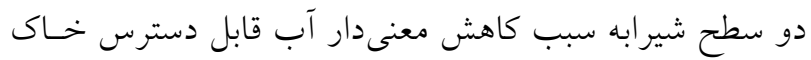

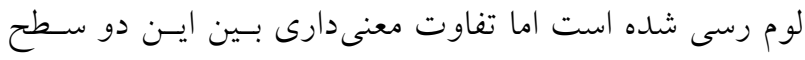
وجود ندارد (جدول 9). كـاهش آب قابـل دسـترس بـا نتـايج

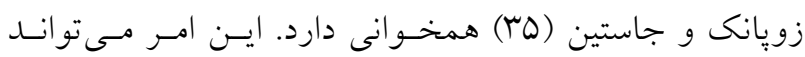

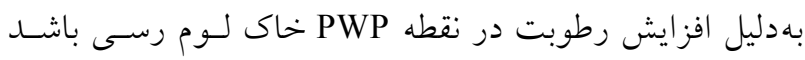

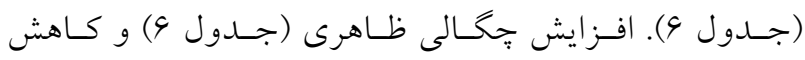

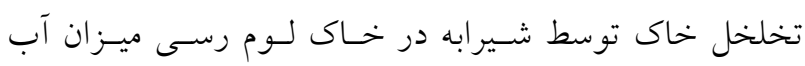

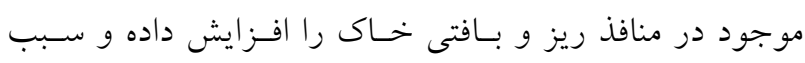

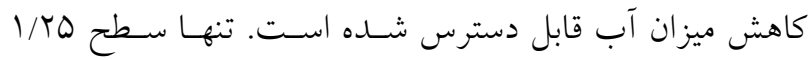

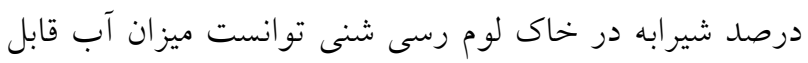

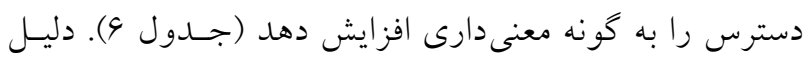

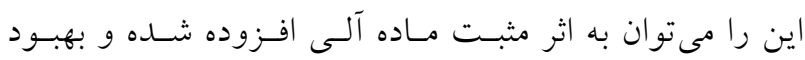
ساختمان خاك لوم رسى شنى توسط شيرابه بيان كرد. كمترين

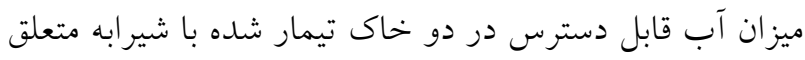

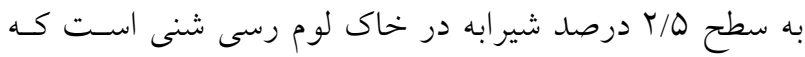

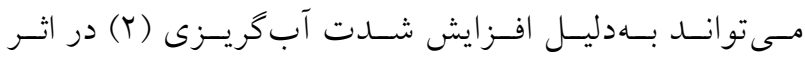

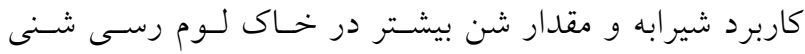
باشد.

اثر شيرابه كميوست بر هدايت هيدروليكى اشباع خاك دو سطح شيرابه، سـبب كـاهش هـدايت هيــرووليكى اشـباع

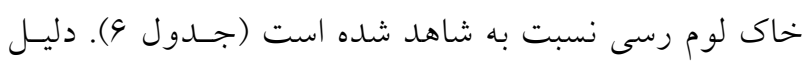

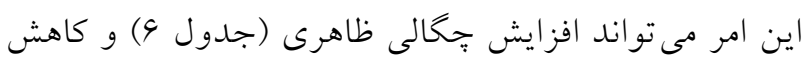


جدول V. ميانخين پارامترهاى حاصل از برازش دو مدل بر دادهاى منحنى مشخصه رطوبتى خاكهاى تيمار شده با شيرابه كميوست

\begin{tabular}{|c|c|c|c|c|c|c|c|c|}
\hline \multicolumn{3}{|c|}{ بروكس و كورى } & \multicolumn{3}{|c|}{ ونخنوختن با محدوديت معلم } & \multirow[b]{2}{*}{ واحد } & \multirow[b]{2}{*}{ يار امتر } & \multirow[b]{2}{*}{ خاى } \\
\hline$\Gamma / Q \%$ & $1 / T \Delta \%$ & $\circ \%$ & $r / Q \%$ & $1 / T \Delta \%$ & $\%$ & & & \\
\hline $0 / 111$ & ०/०ᄉr & $0 / 001$ & O/ANT & $0 / 144$ &.$/ 11$ & $\mathrm{~cm}^{3} / \mathrm{cm}^{3}$ & $\theta r$ & \\
\hline$\circ / 0 \circ \Delta$ & O/YAT & OKYA & $\circ / 01$ & $\circ / 4 \Delta D$ & OKYA & $\mathrm{cm}^{3} / \mathrm{cm}^{3}$ & $\theta s$ & \\
\hline$\circ / I V$ & $\circ / T \circ V$ & O/TYA & $0 / 104$ & $0 / 109$ & $0 / 14 \wedge$ & $1 / \mathrm{cm}$ & $\alpha$ & \\
\hline- & - & - & $1 / 19 V$ & $1 / 14 \wedge$ & $1 / 1 \circ r$ & - & $\mathrm{n}$ & 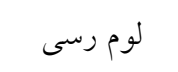 \\
\hline.$/ 114$ & $\circ / 1 \circ 9$ & $\% \vee V Q$ & - & - & - & - & $\lambda$ & \\
\hline ०/००ाr & 010019 & O/O०YI &.$/ 0010$ & $0 / 0019$ & O००YI & $\mathrm{cm}^{3} / \mathrm{cm}^{3}$ & SSQ & \\
\hline$\circ / 91$ & $\circ / 9 V$ &.$/ 90$ &.$/ 91$ & $\circ / 9 V$ &.$/ 99$ & - & $\mathrm{R}^{2}$ & \\
\hline$O /|Y|$ & $\circ \% \mathrm{~V}$ & .094 & $0 / I M Y$ & $\circ \circ V q$ & $\circ \circ \wedge 9$ & $\mathrm{~cm}^{3} / \mathrm{cm}^{3}$ & $\theta r$ & \\
\hline $0 / 44$ & $0 / 419$ &.$/ 494$ &.$/ 4 \& V$ & $\circ / 4 \mid V$ & ./4ar & $\mathrm{cm}^{3} / \mathrm{cm}^{3}$ & $\theta s$ & \\
\hline$\circ / \mu 1 \Lambda$ & $0 /$ HYG & o/AYG & $\circ / T \wedge V$ & $\circ / T V Y$ & $r / \circ \wedge V$ & $1 / \mathrm{cm}$ & $\alpha$ & \\
\hline- & - & - & $|/ Y Y|$ & $1 / I V 4$ & $1 / 101$ & - & $\mathrm{n}$ & لو لوم رسى شنى \\
\hline.$/ 191$ & $\circ / 100$ & 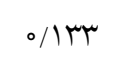 & - & - & - & - & $\lambda$ & \\
\hline \%० TQ & O०OYI &.$/ 0011$ & ०००นa & \%O०YV & 010019 & $\mathrm{~cm}^{3} / \mathrm{cm}^{3}$ & SSQ & \\
\hline.$/ 99$ & $0 / 99$ &.$/ 99$ &.$/ 90$ &.$/ 90$ &.$/ 99$ & - & $\mathrm{R}^{2}$ & \\
\hline
\end{tabular}

سبب شده است كه مدل ونخكنوختن پـارامتر n را بيشـتر از شـاهد

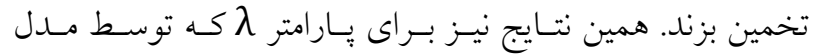
بروكس و كورى تخمين زده شده است بهدست آمد (جدول V). مقدار بيشتر سطح ل/ T/ درصد شيرابه (جدول V)، سـبب شـده اسـت كـه منحنى مشخصه رطوبتى تخمين زده شده با مدل ونخنـوختن و مدل بروكس و كورى براى اين خاك بالاتر از شاهد (لـوم رسى و لوم رسى شنى)، خاى لوم رسى تيمار شده با سـطح ه/ إ درصد شيرابه و خاكهاى لوم رسى شنى تيمار شده با دو سطح شيرابه قرار بخيرد كه مىتواند بهدليل افزايش مـاده آلى خاى توسط شيرابه در اين خاى باشد (شكل (1).
شده با دو سطح شيرابه نسبت به شـاهد كـاهش و در خـاك لوم رسى تيمار شده با شيرابه افزايش يافته است (جدول V). كاربرد شيرابه در دو خاى سبب شده است تا دو مدل مقـدار يارامتر م را كمتر از خاك شاهد تخمين بزنند. كاهش مقدار يار امتر م در مدل ونخْنوختن بـهمعنـاى افـزايش مكش خاك در نقطه عطف منحنى مشخصسه رطـوبتى و در مــل بروكس و كورى بهمعناى افزايش مكش ورود هوا به خاك اسـت

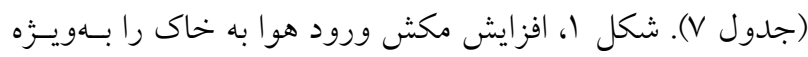
در خاك لوم رسى شنى بهذـوبى نشـان مسىهـــ (منحنسى مــل بروكس و كورى نقطه ورود هوا بـه خـاى را بـهـــورت سـقوط ناخهانى در يك نقطه نشان مىدهد). كـاربرد شـير ابه در دو خـاك 

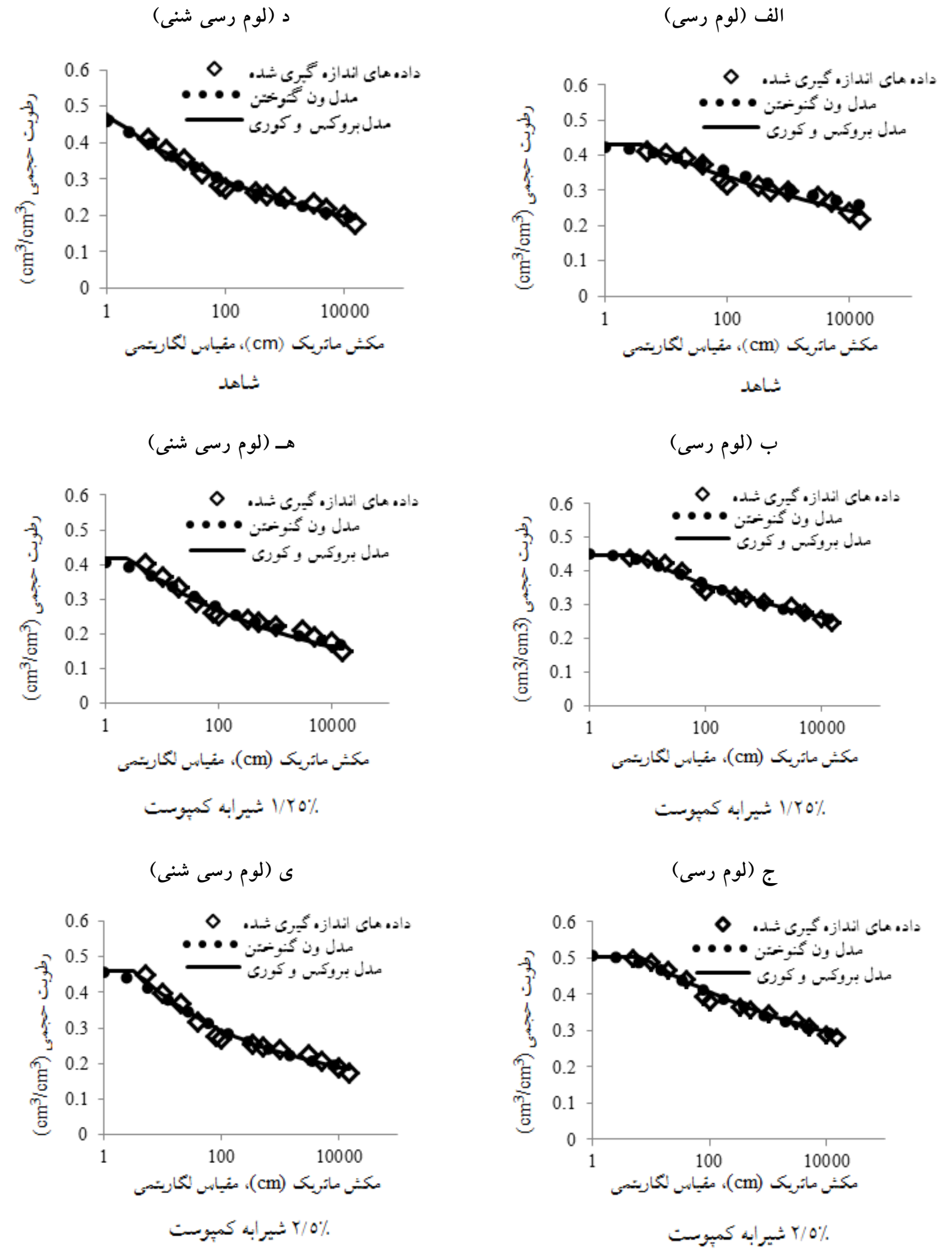

شكل ا. مقايسه برازش دو مدل با يكديخر بر ميانخين دادههاى اندازهيرى شدة نخهداشت رطوبت خاك 
افزايش دو بارامتر n و $\lambda$ بهترتيب در مدلهاى ونخنوختن و

بروكس و كورى بر اثر كـاربرد شـيرابه در دو خـاك، بـهمعنـاى شيرابه در خاك لوم رسى شنى سبب تغييـرات مثبتى از جملـه

افزايش شيب منحنى مشخصه رطوبتى در زمانى است كه خـاك

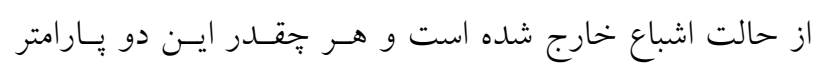
مقادير بيشترى داشته باشند خاك زودتر به نقطه يزمردكى دائمى مىرسد. افزايش مكش ورود هوا در خاك لوم رسى نشاندهنده كاهش تخلخل خاى و در خاى لوم رسى شنى كه داراى بافـت درشتترى نسبت به خاى ديخر است به معناى افزايش تخلخل

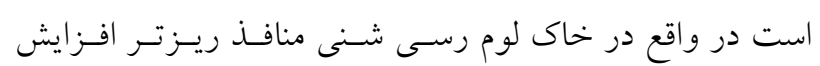
داشته است. نتايج اين بززوهش با يـك بـار تيمـاردهى شـيرابه بـهدسـت

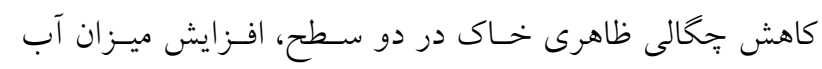
قابل استفاده خاى در سطح ه/T/ درصد و افزايش عملكرد گياه ذرت در دو سطح شده است. اين طور بهنظر مسىرسـد كـاربرد

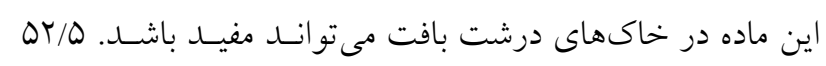

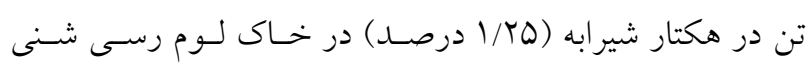
بهدليل افزايش كمتر SAR و افزايش بيشـتر آب قابـل دسـترس

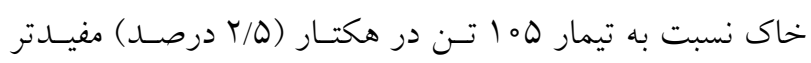
بوده است. البته با توجه به اينكه در اثر كاربرد شيرابه كميوسـت هدايت هيدروليكى اشباع خاك لـوم رسسى شـنى زيـادتر شـده است، مىتواند با ورود به طبيعت به آبهاى زيرزمينى راه بيــا

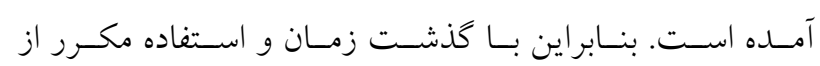

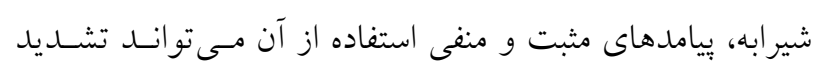
شود.

بيامدهايى از جمله افزايش شورى و جخالى ظاهرى خاك و يا كاهش هدايت هيدروليكى اشباع و آب قابل استفاده در خـاى لوم رسى از جملـه دلايلسى نـامطلوبى اسـت كـه نبايـــ شـيرابه

\section{منابع مورد استفاده}

1. Abedi-Koupai, J. and J. Asadkazemi. 2006. Effects of a hydrophilic polymer on the field performance of an ornamental plant (Cupressus arizonica) under Reduced Irrigation Regimes. Iranian Polymer Journal 15(9): $715-725$.

2. Aelamanesh, P., M. R. Mosaddeghi and A. A. Mahboubi. 2007. On the water repellency and wettability in selected Hamadan soils. In: Proceeding of the $10^{\text {th }}$ Iranian Soil Science Congress, Karaj, Iran. (In Farsi).

3. Afyuni, M., H. Mojtabapor and F. Nourbakhsh. 1997. Salt affected Soils and Reclamation. Arkan, Isfahan. (In Farsi).

4. Alizadeh, A. 2009. Soil Physics. Imam Reza International University, Mashhad. (In Farsi).

5. Al-Yaqout, A. F. and M. F. Hamoda. 2003. Evaluation of landfill leachate in arid climate- a case study. Environment International 29: 593-600.

6. Aryabod, S., A. Fotovat, A. Lakzian and G. H. Haghnia. 2008. Effect of municipal waste compost leachate on micronutrients uptake by maize and lettuce in sterile and non-sterile conditions. Iranian Journal of Soil and Water Sciences 22(1): 47-57. (In Farsi).

7. Astaraei, A. R. and E. Fatahi kiasari. 2006. Effect of municipal waste compost leachate application on some soil chemical properties and green chili plant. Journal of Agriculture 8(1): 1-12. (In Farsi).

8. Brooks, R. H. and A. T. Corey. 1964. Hydraulic properties of porous media. Hydrology Paper Colorado State University, Fort Collins 3: 1-27.

9. Francisca, F. M. and D. A. Glatstein. 2010. Long term hydraulic of compacted soils permeated with landfill leachate. Applied Clay Science 49: 187-193.

10. Gandomkar, A., M. Kalbasi and A. Ghorani. 2003. Effect of compost leachate on yield and chemical composition of corn and the effects of leachate residual on soil characteristics. Pajouhesh-va-Sazandegi (Agronomy and Horticulture) 16(60): 2-8. (In Farsi).

11. Hallett, P. D. and I. M. Young. 1999. Change to water repellence of soil aggregates caused substrate-induced microbial activity. The European Journal of Soil Science 50: 35-40. 
12. Hashemi, H., M. M. Amin, A. Abrahimi and B. Bina. 2014. Survey on quantity and quality of leachate from different steps of municipal Solid Waste Composting in Windrow method. Health System Research 10(1): 142-150. (In Farsi).

13. Hatam, Z. and A. Ronaghi. 2012. Influence of compost and compost leachate on growth and chemical composition of barley and bioavailability of some nutrients in calcareous clay loam soil and sandy soil. Water and Soil Science (Journal of Science and Technology of Agriculture and Natural Resources) 15(58): 109-122. (In Farsi).

14. Kamper, D. W. and R. C. Rosenau. 1986. Aggregate stability and aggregate size distribution. PP. 425-442. In: Klute, A (Ed.), Methods of Soil Analysis (Part 1), American Society of Agronomy, Wisconsin, USA.

15. Khazaei, A., M. R. Mosaddeghi and A. A. Mahboubi. 2008. Impacts of test conditions, soil organic matter, clay and calcium carbonate contents on mean weight diameter and tensile strength of aggregates of some hamedan soils. Water and Soil Science (Journal of Science and Technology of Agriculture and Natural Resources) 12(44): 123-135. (In Farsi).

16. Kjeldsen, P., M. A. Barlaz, A. P. Rooker and A. Baun. 2002. Present and long-term composition of MSW landfill leachate: a review. Critical Reviews in Environmental Science and Technology 32: 297-336.

17. Kladivko, E. J. and D. W. Nelson. 1979. Changes in soil properties from application on anaerobic sludge. Journal (Water Pollution Control Federation) 51: 325-332.

18. Klute, A. 1965. Laboratory measurement of hydraulic conductivity of saturated soil. PP . 210-221. In: Evans, D. D., J. L. White, L. E. Ensminger and F. E. Clark (Eds.), Methods of Soil Analysis (part 1), American Society of Agronomy, Wisconsin, USA.

19. Klute, A. 1986. Water Retention: Laboratory Methods. PP. 635-662. In: Klute, A (Ed.), Methods of soil analysis (Part 1): Physical and Mineralogical Methods, American Society of Agronomy, Wisconsin, USA.

20. Lanyon, L. and W. R. Heald. 1982. Magnesium, Calcium. PP. 247-262. In: Page, A. L. (Ed.), Methods of soil analysis (Part 2), American Society of Agronomy, Wisconsin, USA.

21. Li, J. S., Q. Xue, P. Wang and L. Liu. 2013. Influence of leachate pollution on mechanical properties of compacted clay: A case study behaviors and mechanisms. Engineering Geology 167: 128-133.

22. Lindsay, W. L. 1992. Chemical Equilibria in Soils. John Wiley and Sons. New York.

23. Mirzaei, S. M. J., S. H. Tabatabaei, M. Heidarpour and P. Najafi. 2014. Effect of Compost's Leachate on some Physical and Hydraulic Characteristics of Soil Enriched by Zeolite. Journal of Water and Soil Science 17(66): 3747. (In Farsi).

24. Nasiri, A. 2010. Leachate post-treatment by the combination of ozonation with adsorption process. Master Thesis, Tarbiat Modares University, Tehran, Iran. (In Farsi).

25. Nayak, S., B. M. Sunil and S. Shrihari. 2007. Hydraulic and compaction characteristics of leachate-contaminated lateritic soil. Engineering Geology 94: 137-144.

26. Nourmahnad, N., S. H. Tabatabaei, M. R. Nouri Emamzade, Sh. Ghorbani Dashtaki and A. R. Hoshmand. 2015. Effect of urban sewage sludge application on soil water repellency and water retention curve. Water and Soil Science (Agricultural Science) 25(3): 75-90. (In Farsi).

27. Regalado, C. M. and A. Ritter. 2005. Characterizing water dependent soil repellency with minimal parameter requirement. Soil Science Society of America Journal 69: 1955-1966.

28. Rhoades, J. D. 1982. Soluble salts. PP. 167-179. In: Page, A. L. (Eds.), Methods of Soil Analysis (Part 2), American Society of Agronomy, Wisconsin, USA.

29. Samadi, A. and S. Rezapour. 2017. Effects of waste leachate on the behavior and distribution of the use of some micronutrients in Miandoab. In: Proceeding of the $15^{\text {th }}$ Iranian Soil Science Congress, Isfahan, Iran. (In Farsi).

30. Tillman, R. W., D. R. Scotter, M. G. Wallis and B. E. Clothier. 1989. Water repellency and it's measurement by using intrinsic sorptivity. Australian Journal of Soil Research 27: 637-644.

31. Us Environmental Protection Agency. 1996. Acid Digestion of Sediments, Sludges, and Soil. Method 3050 B. USEPA, Washington, DC. 25-31

32. van Genuchten, M. Th. 1980. A closed-from equation for predicting the hydraulic conductivity for soil. Soil Science Society of America Journal 44: 892-898.

33. van Genuchten, M. Th., F. J. Leij and S. R. Yates. 1991. The RETC code for quantifying the hydraulic functions of unsaturated soils. US Salinity Laboratory, USDA-ARS, Riverside, CA: 85.

34. Veihmeyer, F. J. and A. H. Hendrickson. 1949. Methods of measuring field capacity and wilting percentages of soils. Soil Science 68: 75-94.

35. Zupanc, V. and M. Z. Justin. 2010. Changes in soil characteristics during landfill leachate irrigation of Populus deltoides. Waste Management 30: 2130-2136. 


\title{
Effect of Urban Waste Compost Leachate on the Soil Physical, Hydraulic, Moisture Characteristics and Corn Yield
}

\author{
B. Torabi Farsani ${ }^{*}$ and M. Afyuni ${ }^{1}$
}

(Received: November 5-2018; Accepted: February 13-2019)

\begin{abstract}
Compost leachate is a liquid resulting from physical, chemical and biological decomposition of organic materials. The main objective of this study was to evaluate the influence of leachate compost on the physical, hydraulic and soil moisture characteristic curves. Also, the effect of leachate on the aerial organ fresh weight of corn was investigated. Leachate was added to clay loam and sandy clay loam soils at the rate of zero, 1.25 and 2.5 weight percent. The soil water characteristic curve and the estimation of the parameters of the van Gnuchten and Brooks and Corey models were performed using RETC software. Leachate increased the bulk density and decreased the available water of the clay loam soil. Only $1.25 \%$ of the leachate increased the available water in the sandy clay loam soil. Two levels of leachate decreased the bulk density of sandy clay loam soil. Leachate decreased the saturation hydraulic conductivity of the clay loam and increased this parameter of sandy clay loam soil. Leachate was more successful in increasing the aerial organ fresh weight of corn in the sandy clay loam soil. Therefore, leachate was more useful in sandy clay loam than in clay loam soil, and $1.25 \%$ treatment was better in the sandy clay loam soil. Also, the used leachate increased the repellency of both soils. Leachate caused the parameters of van Gnuchten and Brooks and Corey models to increase, as compared to the control in both soils.
\end{abstract}

Keywords: Compost leachate, Soil moisture characteristic curve, Bulk density, Available water, Saturated hydraulic conductivity.

1. Department of Soil Science, Isfahan University of Technology, Isfahan, Iran.

Corresponding author, Email: bamdadmehr2012@yahoo.com 